\title{
ISLAMIC VALUES OF SOCIAL RELATION IN BESAPRAH TRADITION OF SAMBAS SOCIETY: THE CASE OF POST-CONFLICT MALAY-MADURA IN 1999-2017
}

\author{
ABDUL WAHAB ${ }^{1}$ \\ Institut Agama Islam Negeri Pontianak
}

\begin{abstract}
This paper discusses the effects of inter-ethnic conflict in 1999 on the social life in Sambas. Therefore, any effort dealing with post-conflict situation is needed, through the concept of Islamic character education to modify the Besaprah local wisdom in $\mathrm{Ma}$ lay-Sambas society. This study used a qualitative method with an ethnographic approach which tries to interpret the phenomena in Sambas society since the post-conflict of Malay-Madura in 1999. The research findings show that the inter-ethnic conflict in Sambas, West Kalimantan, occurring in 1999 led to some problems, i.e. moral and social problem, as well as the crisis of local wisdom values. Accordingly, empowering local wisdom values in Besaprah tradition has a contribution to Islamic education concept as it gives an alternative solution to cope with negative effects of the inter-ethnic conflict.
\end{abstract}

Artikel ini membahas dampak konflik antar etnis pada tabun 1999 terhadap kehidupan sosial di Sambas. Karena itu, setiap upaya untuk menghadapi situasi pasca konflik sangat dibutubkan, yaitu melalui konsep pendidikan karakter Islami sebagai modifikasi kearifan lokal Besaprah dalam masyarakat Melayu-Sambas. Penelitian ini menggunakan metode kualitatif dengan pendekatan etnografi yang menafsirkan fenomena masyarakat Sambas pas-

Corresponding author; email: ${ }^{1}$ abdulwahabassambasi@gmail.com.

ISSN 0852-7172 (p) 2461-064X (e)

(C) 2017 Walisongo: Jurnal Penelitian Sosial Keagamaan

http://journal.walisongo.ac.id/index.php/walisongo 
ca konflik Melayu-Madura pada tabun 1999. Temuan penelitian menunjukkan bahwa konflik antar etnis di Sambas, Kalimantan Barat, yang terjadi pada tabun 1999 menyebabkan beberapa masalah, yaitu masalah moral dan sosial, serta krisis nilai-nilai kearifan lokal. Dengan demikian, memberdayakan nilai-nilai kearifan lokal dalam tradisi Besaprah memiliki kontribusi terhadap konsep pendidikan Islam sebagai solusi alternatif untuk mengatasi dampak negatif dari konflik antaretnis.

Keywords: Besaprah; Islamic education; local wisdom; Malay tradition values; violence.

\section{Introduction}

The prolonged conflict in Sambas, West Kalimantan, in January, February and March 1999 left some problems for Malay-Sambas society. Some young people committed unlawful acts such as drinking alcohol and gambling. Moreover, some government apparatus were involved in these forbidden acts (Interview with Leader about Post-Conflict Effect, 2001). In addition, the conflict leads to violations. Interpersonal conflict, for example, ended with fighting that involves many people from both sides. Mass violence becomes a new phenomenon which previously never occurred in Sambas society well-known as friendly and polite people. Pontianak Post (2011) reported that there was torture over Witarsa until he died.

The other accident occurred in Tebas in which people burned the motorcycle showroom. In addition, the obscene shaman was killed. Hence, hundreds of people came to Tebas police office demanding the murderer arrest. There was burned the office and camp of PT Bantanan Eka Jaya (BEJ) in Semanga, Jambu and Desa Sajingan, Kecamatan Sejangkung. And the brawl between two groups of soccer supporters from different villages happened in Sambas followed by house burning in Tebas (Interview 
with Leader about Post-Conflict Effect, 2001). The social relation among ethnic groups gets in trouble after the inter-ethnic conflict. Some people felt to be "heroic" when they could expel other groups. This strange attitude and behavior happened to a small group of a certain ethnic.

After the inter-ethnic conflict, it seems that local wisdom values to fade away. For example, Besaprah tradition is a tradition practiced by Malay-Sambas society for a long time. However, today it is held only in certain moments such as in wedding party and 'aqiqah. It is undeniable that Malay-Sambas society is identical with Muslim who uphold religious values, in addition to traditional values. Malay-Sambas society is well-known as a religious society and even Sambas is called Serambi Mekah. Therefore, the local government efforts to conserve Besaprah tradition should be appreciated. Abdul states that tradition activity is unique in Sambas society and it is predicted that the tradition will not disappear (interview with Leader about Local Wisdom, 2016).

The Regulation of Education and Culture Minister No. 81A, 2013 states that the implementation of guidance curriculum in developing local content as study material in education unit comprises learning content and process about local potency and uniqueness to create students' potential in the area where they live. Furthermore, schools in Kabupaten Sambas have applied local content subject based on local wisdom. However, that subjects do not strengthen the noble values of Malay society. The subject of local content covers Sambas uniqueness such as handicraft, fishery, horticultural, etc, but none of the cultural traditions of Malay-Sambas involved within the subject. Nevertheless, there are still some schools who initiate to integrate the noble values of Sambas society into Islamic Education, inspite of limited coverage. 
Based on the background above, this study is aimed to identify Islamic character values in the local wisdom of Besaprah tradition in Sambas society, as a case of Malay-Madura post-conflict in 1999-2017 as the concept of Islamic education.

This study is aimed to identify Islamic values in the local wisdom of Besaprah tradition in Sambas society. Therefore, this study applied ethnography method to interpret the phenomena in Sambas society since Malay-Madura post-conflict in 1999. The discussion of post-conflict effect and local wisdom values of Besaprah tradition are based on observation and interview with Sambas society and is supported by documentation and literature review to make more accurate and objective findings. The subject of this study covers Malay society in Sambas Regency, West Kalimantan. Data sources for this study are human, event and situation (Nasution 2003)

\section{Previous Studies}

In this section, the author will discuss the relevant literature to generate ideas that this present study will be based on. The first study is Revitalization of Local Wisdom in Process of Socio-Cultural Integration, Case Study of Social Conflict between PT. Inco and Serowako Community, East Luwu, South Sulawesi in 2000-2011 (Siahaan 2013). This study highlighted three structural factors which cause social conflict in 2000-2011, namely land factor, business opportunity, and local workforce. So that local culture is not involved in conflict factors.

The second research is on Revitalization of Social Studies Education Values Based on Local Wisdom (Ethno Pedagogic study on Indigenous People Unitary of Banten Kidul Kesepuhan in Sukabumi Regency) (Hermanto 2012). This study finds that local wisdom of Indigenous People Unitary of Banten Kidul Kesepuhan in Sukabumi Regency includes: geographical phe- 
nomena, religion and view of life, life struggle, occupation, forest management, socio-cultural life and art, and the change of local wisdom and students' insight of local wisdom which are arranged academically, pedagogically, psychologically, and presented in learning process.

Meanwhile the other research studies Greeting in Social Stratification Relation of Malay Riau Language with Siak Dialect: A Socio-pragmatic Study (Evizariza 2015). This study showed that greeting in Malay Riau Language with Sial Dialect is divided into many kinds of greeting. Following the study of greeting is Family Education for Married Couple in Marriage Tradition of Malay-Sambas Community (Kaspullah 2015). This study found that family education for married couple absolutely determines the family harmony, autonomy, and cohesiveness in Malay Sambas community. And the last study is Islamic Education Model for Preschool Children in Malay Sambas Family (Adnan 2005). The research finding showed that there are three goals of religious education for preschool children in Malay Sambas, namely: ideal goal, intermediate goal, and immediate goal.

Based on the results of previous studies, the author asserts that the study on Islamic education in the local wisdom of Besaprah tradition in Sambas society: the case of Malay-Madura post-conflict in 1999-2017 differs from those studies. Therefore, it shows that this study had never been conducted by other researchers. In this regard, the result of this study is original, except several citations and references.

Nevertheless, in this section, the author will present some thoughts related to the theme of study that originates from (S.A. Bekalo 2003) which states that education should be responsive in achieving its target. Education is flexible with formal and non-formal integration system supervised by the government. In 
the same sense, education is oriented to progression and special agenda in social transformation by introducing cultural, politic and economic identity (Cardozo 2014) In the earlier research, Goodbye Conflict, Hello Development? Curriculum Reform in Timor-Leste, about post-conflict education, Ritesh Shah gives encouragement to create a new curriculum which is really different by setting inclusiveness, democracy, and uniqueness.

\section{Theoretical Framework}

Since this study is related the social phenomena regarding the inter-ethnic conflict, some theories presented as analysis tool i.e. conflict structural theory proposed by Karl Marx. This theory states that society actually experiences tension and potential conflict besides various changes within it. The other theory is functional structural theory proposed by Emile Durkheim. This theory views that society tends to create social orderliness so it has a tendency to defend status quo (Maliki 2010). These two theories examine the problem and negative effect of post-conflict.

Furthermore, the theory related to local wisdom proposed by (Alwasilah 2009) views local wisdom from ethno-pedagogic perspective as innovation and skill sources empowered for the social welfare for it has ethno philosophies. Through a whole local wisdom, a society can make peaceful life and increase inter-ethnic welfare (Sibarani 2012).

Meanwhile, the importance of local wisdom to cope with the riots of social life in many regions in Indonesia has been proposed by Minister of Religion. Muhammad Maftuh Basyuniproposes an alternative solution i.e. strengthening local wisdom through some modifications such as government policy on Unitary State of the Republic of Indonesia which is based on the agreement of tradition and religion leaders (Kustini 2008). 
Some people vie that Islamic education is identical with Islamic Institution. This point of view is due to education dichotomy. The view of education dichotomy tends to discriminate one side over the other side. In the other word, the perspective of Islamic education is not only relied on the values of Quran and Hadith, but also the effort to restore Islamic spirit values. Malik Fajar in (Wahab 2013) stated that reposition concept is a view to restore to the actual position.

Islam does not merely talk about doctrine, Islam also talks about the social relationships. Here are the values of Islamic education spirit i.e. to improve human being behavior (Tafsir 2012). The spirit of Islamic education is in line with the values of Besaprah tradition which comprises three primary phases; (1) beginning, (2) core and, (2) ending. Initially, Besaprah tradition begins with the guest's arrival. The guest or people will come because they are invited by the hosts of party. In addition, the invited people will come because they want to make the party successful. The central phase of Besaprah tradition begins with sitting position and eating the food. Based on the observation that the rule of having meal sitting in Besaprah traditions one saprah that consist of six people sitting in semicircular position around the foods placed in the middle position. Moreover, the final stage of Besaprah tradition is the stage of eating food. This is a unique event which generates togetherness value. Each person in saprahan group will hold himself to finish eating the food and not leave the group.

The stages in Besaprah tradition can be seen as the effort to actualize Islamic teaching to fit social development (Azra 1999). In this regard, Islamic education concept is expected to restore Islamic education spirit by seeking and empowering local wisdom values in Malay society. Moreover, education is defined to be a strategic effort to create and change human's character, 
determine the direction of society civilization movement. This meaning is derived from the result of education process which essentially covers existential aspects of human, namely cognitive, affective, and psychomotor aspects.

\section{Result and Discussion}

\section{Study of Conflict Effect}

This study applies the following theories. The first theory is structural conflict theory by Karl Marx. This theory states that society experiences tension and potential conflict and many changes may occur in society. In Sambas society, since the conflict arises, people still feel the tension. This tension occurs in some small groups of society (read: moral decadence actor) who feel neglected by some bigger groups (read: society who tend to deny misconduct by social-cultural moral and norm of Sambas society).

Thus, structural conflict theory vies that negative phenomena of post-conflict are tension and issue diversion from some small groups who lack creativity in facing social reality such as poverty, unemployment, position discrimination in a certain institution. On the other hand, the dominant groups are seen to have less care over the small groups. This finally results in social prejudice, immoral behavior, and the violation acts.

The second theory is a functional structural theory by Emile Durkheim. This theory views that society tends to create social orderliness to defend status quo. In Sambas community, government institutions and social regulation do not really function well. Society and religious leaders and security apparatus are less able to anticipate the post-conflict social phenomena. This seemingly occurs due to lack effort in building communication on the problem with those small groups. 
Based on this functional structural theory, Malay Sambas society attempt to end the conflict and remove the post-conflict effect. This means that Malay Sambas society, who are basically religious and sambas are labeled the second serambi mekah after Aceh, desire the harmonious society. One action to be taken is building more verbal and non-verbal communication in inter-ethnic groups. In the other word, this interaction only can be realized through inviting and involving all society members, one of which is through Besaprah tradition.

Furthermore, Malay Sambas society is well-known to have accommodative character. Perhaps one factor that shapes Malay culture system is their living around the upstream of the river (Collins 2005) which means that they can live in harmony with the different ethnic groups. They are, however, united in one tradition called Besaprah.

\section{Local Wisdom in Besaprah Tradition}

This study is focused on the local wisdom of Besaprah tradition in Malay Sambas ethnic. Based on the research findings, here are the things related to Besaprah tradition as follow:

a. History and Definition of Besaprah tradition.

Historically, nobody knows how Besaprah tradition emerged. According to some sources that this tradition emerged as a respect or honor is given by host to the guests who traveled for long distance by serving foods collectively for them and by sitting with a crossed foot or 'beselak'. Thus, Besaprah actually means eating together as honoring guests tradition that Malay-Sambas society have been practicing for a long time (interview with Safiudin about Besaprah Tradition, 2015).

b. The Elements and Symbols of Besaprah tradition.

Besaprah tradition comprises the following elements: first, there should be 1 (one) rice which symbolizes that life source 
is just one namely Allah who has given the life and fortune that human must thank for. Second, there should be 2 (two) spoons of fish/ meat/ vegetables, etc which symbolize the declaration of two syahadat as the key of human faith. Third, there should be 5 (five) pekare (read: sort of) fish/ meat/ vegetables as a symbol of five pillars of Islam in which every Muslim must observe. Forth, there should be 6 (six) people in sesaprah as a symbol of six basic pillars of faith which should be integrated into human life. Fifth, there should be one small container filled with clean water to wash hand. Water for washing hand is served as a symbol of physical and mental cleanness when human build relation with another human or relation with Allah (interview with Safiudin about Besarpah Tradition, 2015.

c. The Process of Besaprah tradition

Generally, all activities in Besaprah tradition consist of three stages, namely beginning, core and end. All activities are strongly related to each other. In the initial stage, Besaprah eating tradition begins with the guest's arrival. The guests come from near or far location because they have to attend the invitation. Basically, the guest or people will come because they are disarok (read: invited) by the hosts such as in wedding party. The invited people come because they want make the party successful. In this initial phase, the guests arrival is followed by various dressing styles wore by the guests and host. The guests will enter tarup and place suitable to their dressing style. The event will begin with the series of opening, welcoming speech, followed by zikiran or tausiyah, and ends with pray.

Afterward, the core stage of Besaprah tradition begins with sitting position and eating food. Based on the observation that the rule of having a meal sitting in Besaprah traditions one saprah that consist of six people sitting in semicircular position around the foods placed in the middle position. With this position, they can eat without spoons and they sometimes talk to each other. 
The ending stage of Besaprah tradition is a stage to finish eating foods. To finish eating foods in Besaprah tradition has a unique phenomenon which generates togetherness value. Each person in saprahan group will hold himself or herself to finish eating foods and not leave the group.

d. People Involved in Besaprah Tradition

According to Erwin Mahrus and Andi Gidang, in eating ceremony in Besaprah, the involved people are those who are invited including relatives, neighbors, religious leaders and society leaders. Even, there are people who come from the neighboring villages depending on the party. The numbers of people involved depend on the numbers of invitation distributed and host capability to hold the party (Gidang 2010).

e. Values in Besaprah Tradition

Based on observation and interview results of Besaprah tradition in Malay-Sambas society, there are some local wisdom values which to be raised. These values are as follow:

The first value is togetherness. Togetherness means the collective effort done by some people or group of people in achieving a certain goal. In Besaprah tradition of Malay Sambas society, the value of togetherness will be seen in guests and people attending. It is also seen from sitting position and finishing eating food.

The second values are intimacy and good relationship. Intimacy and good relationship mean the effort to begin interaction by communication so it creates social and emotional bonding. In Besaprah tradition of Malay Sambas society such as wedding party, there is an effort to begin interaction by communication during eating Besaprah which in turn build a continuous relationship outside besaprahan tradition.

The third value is removing the ego. In Besaprah tradition, it is hoped that all people have the awareness to suppress their 
desire to control others by communication and eating foods. All should keep this attitude by giving a chance to other people and try to create a condition of a good relationship. In tradition, Malay Sambas society believes that the main vehicle of communication is asking and answering the question.

The fourth value is a willingness to share. This value comes after removing the ego. A willingness to share is personal effort to give other people a chance to enjoy something in order to create a justice. In Besaprah tradition in Malay Sambas society, willingness and effort of each person in sesaphahan (read: one group of saprah) means to give a chance to other to enjoy food evenly. So, a willingness to share in Besaprah tradition is satisfaction value in Malay Sambas society.

The fifth value is hospitality. The hospitality in Malay-Sambas society is actualized by communication and interaction during Besaprah tradition. The hospitality in Malay-Sambas society has a great contribution to Besaprah tradition.

The sixth value is ethic. Ethic is a set of unwritten rules about the conduct considered as good according to a society. In Besaprah tradition, this means that there are some good conducts according to Malay-Sambas society which should accompany this tradition. Ethics covers rules in dressing, sitting which is adjusted to the way of dressing. The ethic of Besaprah requires six people in one group to enjoy the food.

The seventh value is self-honor. Self-honor means the values related to one's good reputation in the sight of society. In Malay-Sambas society, a person should maintain his good reputation, his parent, and family good reputation as well. In Besaprah tradition of Malay-Sambas society, self-honor means the values related to a person's good reputation by maintaining the culture of suppan (read: ashamed) for both the host and the guests in 
Besaprah tradition. In Besaprah tradition, the value of self-honor is expressed into two things, namely dressing style and the place where one stays.

Therefore, based on value analysis of Besaprah tradition in Malay-Sambas society, this tradition is full of local wisdom values and religious values. The implementation of local wisdom values in social life as a guide can determine a society's identity and quality in building and developing peaceful and welfare relationship. However, the identity creation should be supported by the society members as the actors in implementing tradition. This support and commitment can be seen in the habituation of Besaprah tradition.

According to Alwasilah that local wisdom in ethno-pedagogic perspective is the sources of innovation and skill which can be empowered for social welfare for it has ethno philosophies. In this regard, Besaprah tradition generates noble values which have socio-cultural spirits and religious spirit, so it can be the sources of innovation and skill to build the welfare of Malay-Sambas society. In Sambas language, the word welfare derived from the word sejabtre which means secure, prosperous, and safe. Sejahtre sometimes means gammok' (read: fat body), kaye (read: rich person). Welfare is a condition in which all life needs are fulfilled, particularly the basic needs such as food, clothes, house, education, security and health.

Local wisdom is originated from cultural value and norms of an ancestor who concerned with human's life problem and really concerned in preparing the life of next generation (Sibarani 2012). In addition, according to (Koentjaraningrat 2009) that cultural elements consist of language, knowledge system, social organization, religious system, and art, and so does Besaprah tradition of Malay Sambas society. 


\section{Islamic Values in Besaprah Tradition}

According to Ahmad Tafsir, the concept of Islamic education is helping one to become a whole man; have self-control which means a good character, love his motherland and posses knowledge and right thinking. Education is aimed to help human to become real human (Tafsir 2012). The word 'help' means direct human to do the right thing. Moreover, education does not only humanize man, but also build his mental to produce a civilized and cultured generation with magnificence principle (Ulwan 1995).

Therefore, Islamic education can be contextualized in terms of achieving the goal of human life i.e. attempting to cultivate the wisdom of cultural values in accord with Islamic principle of ketauhidan. In Islamic education perspective, rahmatan li al'àlamin $n$ highlights the moral and value of ketaubidan. Thus, the message in the values of Besaprah tradition is suitable to create good character (Tafsir 2008). Meanwhile, Malik Fajar views reposition concept by seeing the values of Besaprah tradition whether they are contradictory to the values of Quran and Hadith. Hence, the right perspective is required in understanding a based-Islamic values tradition.

Misunderstanding Islam will mislead the meaning of Islam. Islam does not only cover theocentric domain but also an anthropocentric aspect. Islam identity as a religion of rabmatan li al-'âlamīn (bring God's blessing for entire world) will generate a harmonious social relations. This means that the value of Islamic education spirit is to improve human character (Tafsir 2012). Even local tradition can be interpreted by the paradigm of taubid (Azra 1998). The paradigm of taubìd sees God not

only the One and Only God but also integrates all aspects and all point of views. 
Besaprah tradition comprises three primary phases; (1) beginning, (2) core and, (2) ending. Initially, Besaprah tradition begins with the guest's arrival. The guest or people will come because they are invited by the hosts of the party. In addition, the invited people will come because they want to make the party successful. The central phase of Besaprah tradition begins with sitting position and eating the food. Based on the observation that the rule of having a meal sitting in Besaprah traditions one saprah that consist of six people sitting in semicircular position around the foods placed in the middle position. Moreover, the final stage of Besaprah tradition is the stage of eating food. This is a unique event which generates togetherness value. Each person in saprahan group will hold himself to finish eating the food and not leave the group.

There are some moral values in the phases of Besaprah tradition that are in line with the noble Islamic values, such as respecting guest, togetherness, intimacy and good relationship symbolized in sitting position and the way of eating. Islamic education includes the whole values in the tradition. In the other words, the perspective of Islamic education does not merely depend on textual Quran and Hadith, it, however, is based on an effort to restore the spirit of Islamic values. In addition to doctrine, Islam talks about the social relationships. The spirit of Islamic education within Besaprah tradition is improving human's intelligence quotient (IQ), emotional quotient (EQ) and spiritual quotient (SQ).

\section{Conclusion}

As an effort to cope with post-conflict effects, Malay-Sambas society (1) on one side need to make changes, namely: a. doing cultural transformation through education which is not conflicting with cultural values so-called local wisdom and b. 
internalization method by offering the way to view educational problem by knowing, doing, being. (2) On the other side, the effort to preserve cultural values in Sambas is in accordance with life philosophy and based on tradition as the sources of innovation and skill which can be empowered in family, school and community environment in the light of Islamic education, thus (3) finally local wisdom is aimed to create harmonious social relation, improve human character and the welfare of Malay and non-Malay society by setting spirit of Islamic education as rahmatan li al-'álamīn.

\section{Bibliography}

Adnan. 2005. "Model Pendidikan Agama Anak Usia Prasekolah Dalam Keluarga Melayu Sambas.” UIN Sunan Gunung Djati Bandung.

Alwasilah, A. C. 2009. Etnopedagogi, Landasan Praktek Pendidikan Dan Pendidikan Guru. Bandung: PT Kiblat Buku Utama.

Azra, Azyumardi. 1998. Rekontruksi Pendidikan Dan Tradisi Pesantren, Religiusitas Iptek. Yogyakarta: Pustaka Pelajar.

- 1999. Pendidikan Islam, Tradisi Dan Modernisasi Menuju Milenium Baru. Jakarta: Logos Wacana Ilmu.

Cardozo, R. S. 2014. "In Education and Social Change in Post-Conflict and Post-Disaster Aceh Indonesia." University of Auckland New Zealand.

Collins, J. 2005. Bahasa Melayu Bahasa Dunia: Sejarah Singkat. Edited by Almanar Elma Evita. Jakarta: Yayasan Obor Indonesia.

Evizariza. 2015. "Sapaan Dalam Hubungan Stratifikasi Sosial Bahasa Melayu Riau Dialek Siak: Satu Kajian Sosiopragmatik.” Bandung: Universitas Padjadjaran Bandung. 
Gidang, E. M. 2010. Tradisi Dan Komunikasi Orang Melayu (Tradisi Yang Membelajarkan). Pontianak: STAIN Pontianak Press.

Hermanto. 2012. "Revitalization of Social Studies Education Values Based on Local Wisdom (Ethno Pedagogic Study in Indigenous People Unitary of Banten Kidul Kesepuhan in Sukabumi Regency)." Universitas Pendidikan Indonesia Bandung.

Kaspullah. 2015. "Pendidikan Keluarga Bagi Pasangan Pengantin Dalam Tradisi Pernikahan Masyarakat Melayu Sambas.” UIN Sunan Gunung Djati Bandung.

Koentjaraningrat. 2009. Pengantar Ilmu Antropologi. Jakarta: Rineka Cipta.

Kustini. 2008. "Tradisi Modernisasi Dan Keharmonisan Umat Beragama." Jurnal Multikultural Dan Multireligius 7 (27).

Maliki, Z. 2010. Sosiologi Pendidikan. Yogyakarta: Gadjah Mada University Press.

Nasution, S. 2003. Metode Penelitian Naturalistik Kualitatif. Bandung: Tarsito.

S.A. Bekalo, M. B. 2003. The Development of Education in Post-Conflict Somaliland. London: University of Leeds.

Siahaan, J. T. 2013. Revitalization of Local Wisdom in Process of Socio-Cultural Integration: Case Study of Social Conflict between PT. Inco and Serowako Community, East Luwu, South Sulawesi in 2000-2011. Bandung: Universitas Padjajaran.

Sibarani, R. 2012. Kearifan Lokal, Hakikat, Peran Dan Metode Tradisi Lisan. Jakarta: Asosiasi Tradisi Lisan.

Tafsir, A. 2008. Pesan Moral Ajaran Islam. Bandung: PT. Remaja Rosdakarya.

— 2012. Filsafat Pendidikan Islam. Bandung: PT. Remaja Rosdakarya. 
ABDUL WAHAB

Ulwan, A. N. 1995. Pendidikan Di Rumah, Sekolah Dan Masyarakat. Jakarta: Gema Insani Press.

Wahab. 2013. Kapita Selekta Pendidikan Islam. Pontianak: STAIN Pontianak Press. 